\title{
Influence of Implant Surfaces on Osseointegration
}

\author{
Arthur Belém NOVAES Jr. ${ }^{1}$ \\ Sérgio Luis Scombatti de SOUZA ${ }^{1}$ \\ Raquel Rezende Martins de BARROS ${ }^{1}$ \\ Karina Kimiko Yamashina PEREIRA ${ }^{1}$ \\ Giovanna IEZZI ${ }^{2}$ \\ Adriano PIATTELLI ${ }^{2}$

\begin{abstract}
${ }^{1}$ Department of Oral and Maxillofacial Surgery and Traumatology and Periodontology, Ribeirão Preto Dental School, University of São Paulo, Ribeirão Preto, SP, Brazil
\end{abstract} \\ ${ }^{2}$ Dental School, University of Chieti-Pescara, Chieti, Italy
}

\begin{abstract}
The biological fixation between the dental implant surfaces and jaw bones should be considered a prerequisite for the long-term success of implant-supported prostheses. In this context, the implant surface modifications gained an important and decisive place in implant research over the last years. As the most investigated topic in, it aided the development of enhanced dental treatment modalities and the expansion of dental implant use. Nowadays, a large number of implant types with a great variety of surface properties and other features are commercially available and have to be treated with caution. Although surface modifications have been shown to enhance osseointegration at early implantation times, for example, the clinician should look for research evidence before selecting a dental implant for a specific use. This paper reviews the literature on dental implant surfaces by assessing in vitro and in vivo studies to show the current perspective of implant development. The review comprises quantitative and qualitative results on the analysis of bone-implant interface using micro and nano implant surface topographies. Furthermore, the perspective of incorporating biomimetic molecules (e.g.: peptides and bone morphogenetic proteins) to the implant surface and their effects on bone formation and remodeling around implants are discussed.
\end{abstract}

Key Words: dental implants, topography, surface modifications, biomimetic coating, osseointegration.

\section{INTRODUCTION}

Osseointegration is seen as the close contact between bone and implant (1), and the interest on surface engineering has to be understood as an important and natural trend. The bone response, which means rate, quantity and quality, are related to implant surface properties. For example, the composition and charges are critical for protein adsorption and cell attachment (2). Hydrophilic surfaces seem to favor the interactions with biological fluids and cells when compared to the hydrophobic ones $(3,4)$, and hydrophilicity is affected by the surface chemical composition.

Various techniques of surface treatments have been studied and applied to improved biological surface properties, which favors the mechanism of osseointegration $(5,6)$. This strategy aims at promoting the mechanism of osseointegration with faster and stronger bone formation, to confer better stability during the healing process, thus allowing more rapid loading of the implant $(7,8)$.

Some of the objectives for the development of implant surface modifications are to improve the clinical performance in areas with poor quantity or quality of bone, to accelerate the bone healing and thereby allowing immediate or early loading protocols and also stimulating bone growth in order to permit implant placement in sites that lack sufficient residual alveolar ridge, thus providing them a jumping gap ability, for example.

Implant morphology influences bone metabolism: rougher surfaces stimulates differentiation, growth and attachment of bone cells, and increases mineralization; furthermore, the degree of roughness is important. Implants may have "smooth" (machined) or rough

Correspondence: Prof. Dr. Arthur B. Novaes Jr., Departamento de Cirurgia, Traumatologia Buco-Maxilo-Facial e Periodontia, Faculdade de Odontologia de Ribeirão Preto, Universidade de São Paulo, Avenida do Café, S/N, 14040-904 Ribeirão Preto, SP, Brasil. Tel: +55-16-3602-3979 Fax:+55-16-3602-4788. e-mail: novaesjr@forp.usp.br 
surfaces. The main methods that are reported in the literature to create implant roughness are acid etching, sandblasting, titanium plasma spraying and hydroxyapatite (HA) coating. A current tendency is the manufacturing of implants with micro and submicro (nano) topography. Furthermore, the biofunctionalization of implants surfaces, by adding different substances to improve its biological characteristics, has also been recently investigated (8-10).

However, the large number of commercially available implant types, varying in surface properties and other features (11) have to be treated with caution. Considering that different methods for implant surface engineering may lead to different and unique surface properties that might affect the host-to-implant response, it seems to be reasonable to test new implant surfaces as new biomaterials (12). The evaluation should ideally follow a hierarchical approach, where in vitro testing followed by in vivo animal studies evolves to clinical trials in humans (13).

This paper reviews the literature on dental implant surfaces by assessing in vitro and in vivo studies to show the current perspective of implant development.

\section{IN VITRO STUDIES}

Cell culture models are routinely used to study the response of osteoblastic cells in contact with different substrates for implantation in bone tissue. Cell cultures focused on the morphological aspect, growth capacity and the state of differentiation of the cells on materials with various chemical, composition and topography (14).

The literature shows that the biochemistry and topography of biomaterials' surfaces play a key role on success or failure upon placement in a biological environment (15). Wettability, texture, chemical composition and surface topography are properties of the biomaterials that directly influence their interaction with cells (16-18). The interactions of cells and extracellular matrix affect directly the cellular processes of adhesion, proliferation and differentiation (19). Thus, the surface properties of biomaterials are essential to the response of cells at biomaterial interface, affecting the growth and quality of newly formed bone tissue $(16,17,20)$.

In the search for new methods, much attention has been focused on topographical characteristics, especially changes in surface roughness. In vitro studies have shown that osteoblastic cells attach, spread and proliferate more rapidly on smooth surfaces than on rough ones (21). However, osteoblasts present higher rate of differentiation and matrix mineralization and higher production of growth factors in the presence of rough substrates (22). Also, bone matrix proteins, alkaline phosphatase and osteocalcin, important indicators of osteogenic differentiation and bone tissue formation, have been shown to express at higher levels on rougher titanium surfaces (23).

The literature has shown that the surface topography of titanium can be modified by different treatments, in order to obtain a surface with specific properties, which have direct influence on the process of osseointegration $(24,25)$. It has been suggested that surface roughness in 1-2 $\mu \mathrm{m}$ range are beneficial for biomechanical anchorage of dental implants (26).

Methods for altering surface texture can be classified as either techniques that add particles on the biomaterial, creating a surface with bumps (additive mechanisms), and techniques that remove material from the surface, creating pits or pores (subtraction mechanisms). Examples of additive processes are: HA and calcium phosphate $(\mathrm{CaP})$ coatings, titanium plasmasprayed and ion deposition. Examples of subtraction processes are: electro- or mechanical polishing, gritblasting, acid-etching, grit-blasting followed by acidetching and oxidation (27).

Numerous reports demonstrate that the surface roughness of titanium implants affects the rate of osseointegration through the speed and amount of bone tissue formed at the interface. Comparison of the behavior of different cell types on materials shows that they are influenced by surface roughness (28).

Roughness gradients of osteoblastic cells increase proliferation in close correlation with increasing surface roughness. It was observed doubling of the rate of osteoblast proliferation on titanium blasted with $\mathrm{TiO}_{2}$ particles compared to smooth surfaces $(29,30)$. Similar results are reported using discs blasted with $\mathrm{SiO}_{2}$ particles (31), and $\mathrm{Al}_{2} \mathrm{O}_{3}$ particles (29).

Subcultures of rat osteogenic cells grown on grit-blasted and acid-etched surfaces demonstrated significant formation of bone-like nodules (32). MG63 osteoblast-like cells (human osteosarcoma cell line) cultured on rough titanium surfaces exhibited increased adhesion and phenotype differentiation, and higher levels of growth factors compared to smooth ones (4).

There is agreement that the microtopography creates an environment favorable for cells and cellextracellular matrix interactions (33) and increases 
production of growth factors (34). The microtopography provides increased cell differentiation of osteogenic cells, resulting in high activity of alkaline phosphatase and osteocalcin synthesis (35).

Recent studies have shown that the association of different topographies may be beneficial. Indeed, using osteogenic cell culture models, synergistic effects of substrates with micron- and submicron-scale resulting in bone tissue formation have been reported $(30,32)$. Titanium surfaces with microtopography and additional submicrotopography have been shown to promote early development of mineralized matrix, which was observed occasionally on the surfaces with microtopography and was absent on machined surfaces (36).

The cellular behavior is also influenced by surfaces with nanomorphology. The complex interactions cellmatrix-substrate and cell signaling events occur at the nanoscale $(37,38)$. Different signaling pathways regulate adhesion, migration, differentiation and gene expression in osteoblasts cells (39). Thus, it has been shown that different nanotopography influence protein adsorption, cell adhesion, cell proliferation and synthesis, and secretion of extracellular matrix molecules in vitro (37).

Nanoporous surfaces topography tend to favor the proliferation and differentiation processes, acting directly on the selective adhesion of osteoblastic cells on the surface, which can accelerate the healing process around implants $(27,37)$.

In the same way as microstrutureted surfaces, nanotopographies can be created by techniques such as anodization and oxidation. The production of substrates with nanoporous surfaces appears to strongly influence the host response at both cellular and tissue levels (12).
A recent report demonstrated that titanium surfaces with nanotopographies obtained from $\mathrm{H}_{2} \mathrm{SO}_{4} / \mathrm{H}_{2} \mathrm{O}_{2}$ mixture can promote osteoblast proliferation and inhibit fibroblast growth (40). It was found that titanium surface modifications on the nanoscale alters the adhesion, spreading, and growth of osteoblastic cells. Furthermore the extracellular accumulation of osteopontin and bone sialoprotein, two major bone matrix proteins, increased significantly on the titanium substrate with nanotopography, indicating that cellular differentiation is accelerated, and the proteins are adsorbed more efficiently on the nanostrutured substrates (41).

At the present moment, a huge number of experimental investigations have clearly demonstrated that the bone response is influenced by the implant surface topography. Furthermore, more recent data, have suggested that titanium surface modifications with bioactive molecules enhance and/or accelerates the process of osteoblastic differentiation. As the molecules are integrated into the structure of the implant, they are released gradually, acting as a slow release system of osteogenic agents at the implantation site (42) (Fig. 1).

Among all engineering-based implant surface modifications, the $\mathrm{CaP}$ coating have received significant attention (43). The interest of using this material is because of its chemical similarity to natural bone, and the fact that coatings can be applied along the implant surfaces by different industrial processing methods. Biomimetic CaP coatings improve the osteoconductivity of implants and show promising as slow delivery systems for growth factors and other bioactive molecules (44).

Other examples of biochemical modifications of biomaterial surfaces are found in the literature, such as
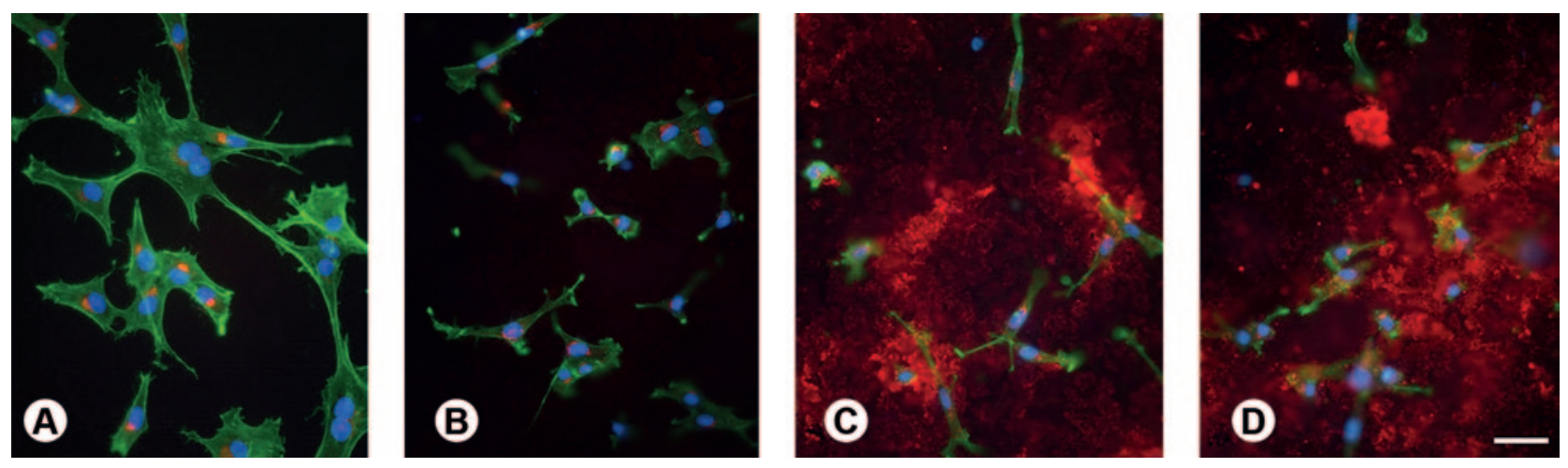

Figure 1. Epifluorescence of osteogenic cell cultures grown on machined (A), microstructured (B), nanostrutured (C), and synthetic peptide coating (D) surfaces at day 3. Red indicates OPN labeling, green reveals actin cytoskeleton, and blue shows cell nuclei. Extracellular OPN labeling is abundant and prominent in cultures grown on nanostrutured and synthetic peptide coating surfaces (C,D). Scale bar: A-D=50 $\mu \mathrm{m}$. 
the use of protein-like collagen, bone morphogenetic proteins and peptides and/or protein domain (27).

The biological effects that surfaces have on cell attachment are mainly mediated by integrins that bind to sequences/domains arginine-glycine-aspartate (ArgGly-Asp or RGD) of proteins (45). These Arg-Gly-Asp or RGD are expressed in several bone extracellular matrix proteins. Titanium surfaces modified with peptides and/ or protein domains with RGD seem to facilitate the mechanisms of adhesion and cell signaling via signal transduction, which have shown positive effects on the differentiation of osteoblasts (46).

Since then, researchers have studied coatings based on peptides containing a sequence of amino acids to promote cell adhesion to the biomaterial (47). A new strategy in the use of bioactive molecules involves the addition of extracellular matrix proteins such as collagen. Coating titanium surface with collagen enhanced the spreading of cells and speeding cell adhesion length (48). An in vitro study using bone marrow cells also showed that surface coating with collagen type I showed high ALP activity, collagen synthesis, and mineralized matrix formation (49).

A recent study comparing the development of the osteoblastic phenotype of human alveolar bonederived cells showed that collagen type I-coated titanium surface favors cell growth during the proliferative phase and osteoblastic differentiation, as demonstrated by changes in mRNA expression profile during the matrix mineralization phase. This suggests that surface modification may affect bone formation (50).

Some authors have used chemical modification, such as addition of fluoride to implant surface, to improve the biocompatibility of titanium and promote osteogenesis. This process is based on the formation of fluorapatite from interaction of fluoride and HA present
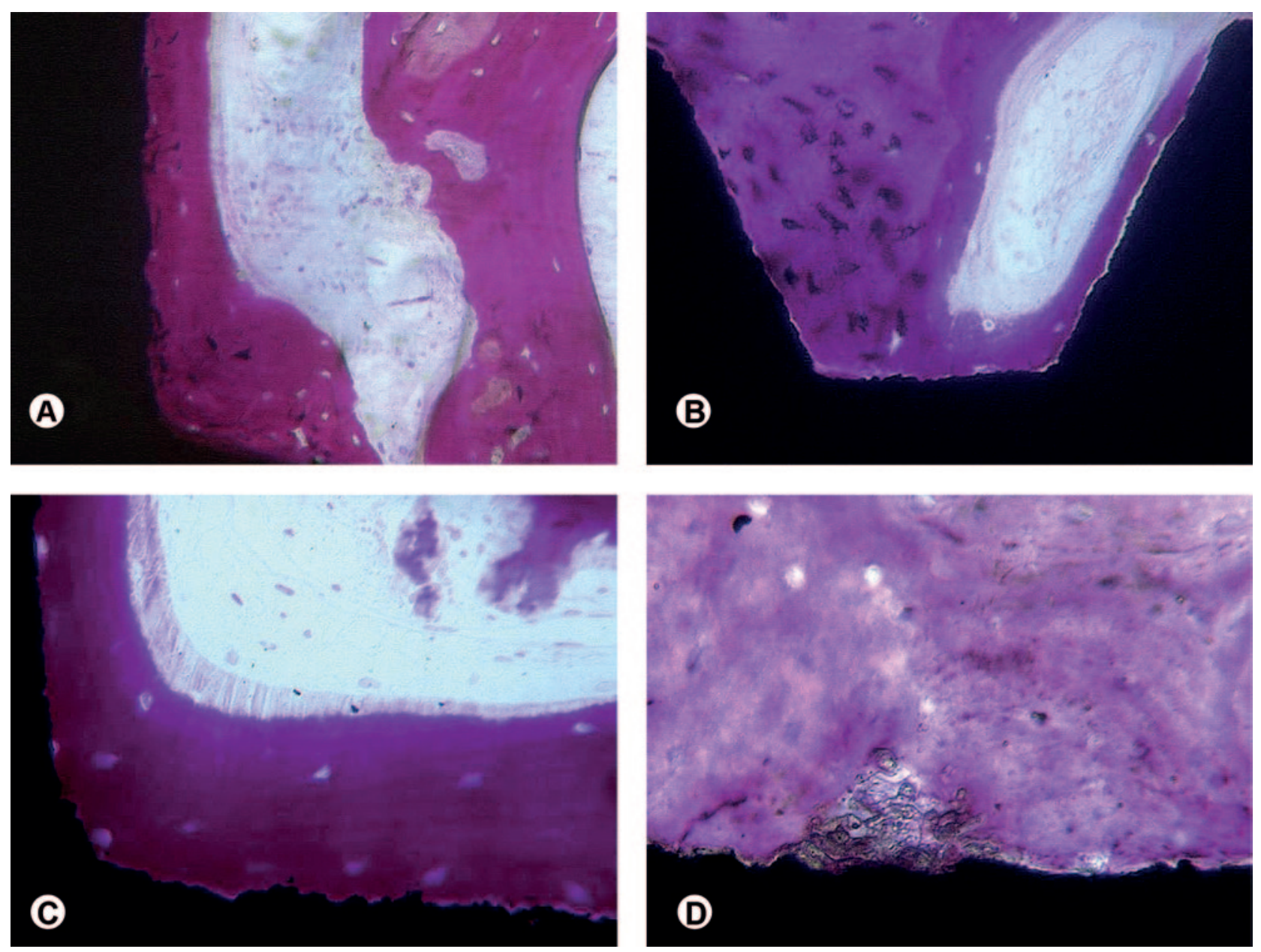

Figure 2. Histologic images evidencing a high level of bone-implant contact achieved with different improvements on implant surfaces. $\mathrm{A}=$ Sandblasted and acid-etched; $\mathrm{B}=$ Nanostructured; $\mathrm{C}=$ Anodized; $\mathrm{D}=$ Biofunctionalized. 
in bone tissue, followed by promotion of osteoblast proliferation and stimulation of alkaline phosphatase activity. Currently, there are implants treated with fluoride as a biomimetic agent, commercially available for clinical use (51).

Despite the interesting results in vitro it seems that more research is still needed to enhance our understanding of how this surface modifications actually promotes fast osseointegration.

\section{IN VIVO ANIMAL STUDIES}

In general, cell culture studies evaluate cell morphology, adhesion, migration, proliferation and differentiation on implant surfaces. However, outcomes on the initial biological behavior of new biomaterials obtained in vitro cannot be fully correlated to in vivo performance. Cell cultures cannot reproduce the dynamic environment that involves the in vivo bone/implant interaction, and their results can only be confirmed in animal models and subsequently in clinical trials (13).

The most frequently used animal models for dental bone-implant interface studies are rabbits and dogs. The rabbit model has some disadvantages when compared to larger animals, such as the size when a number of control and experimental implants are recommended per animal. Additionally the bone structure of the tibia and femur of rabbits (e.g.; the amount of trabecular bone), are significantly different when compared to human. Otherwise the canine intraoral environment provides a bone microstructure with a trabecular/cortical ratio similar to that found in the human mandible, in addition to similar saliva and microflora.

Irrespective to the different animal models (rat, rabbits, sheep, dogs, pigs or nonhuman primates) or surgical sites, valuable information can be retrieved from properly designed animal studies. Static and dynamic histomorphometric parameters plus biomechanical testing are recommended as measurable indicators of the host/implant response where different surface designs are compared. Bone-to-implant contact (BIC), which that is the most often evaluated parameter in in vivo studies, together with bone density and amount and type of cellular content, are examples of static parameters. Differently, mineral apposition rate and fluorescence analysis temporally evaluates bone modeling/remodeling processes. As dynamic measurements, they may provide valuable information about the healing around different implant surfaces, but these parameters are rarely used.
Finally, the biomechanical tests (torque, push-out, pullout) usually measure the amount of force that a torque needs to fail the bone-implant interface surrounding different implant surfaces.

Considering the several factors that influence the osseointegration, the evaluation of the largest possible number of host/implant response parameters is desirable for better understanding the bone healing around different implant surfaces (Fig. 2), clarifying their indications of use and supporting their immediate/ early loading. For descriptive purposes, the physical and chemical surface properties will be separated in different categories.

\section{Topographic Surface Modifications}

Machined implant surfaces represent the starting point of implant surface design. They were used for decades according to the classical protocols in which several months were required for osseointegration (52).

It has been demonstrated that the modification on the topographic pattern of surface increases not only the bone-implant contact, but also the biomechanical interaction of that interface at early implantation periods (1). Rough surfaces have found widespread use in oral implantology and replaced implants with machined surfaces to a great extent in clinical applications (46).

Various methods have been developed in order to create a rough surface and improve the osseointegration of titanium dental implants. These methods use titanium plasma-spraying, blasting with ceramic particles, acidetching and anodization.

\section{Titanium plasma-spraying}

This method consists in injecting titanium powders into a plasma torch at high temperature. The titanium particles are projected onto the surface of the implants where they condense and fuse together, resulting in a titanium plasma sprayed (TPS) coating with an average roughness of around $7 \mu \mathrm{m}$. This procedure increases substantially the surface area of the implants.

Al-Nawas et al. (53) evaluated different types of macro and microstructure implant surfaces in a dog model. After a healing period of 8 weeks and a loading period of 3 months, machined surfaces were compared to the TPS counterparts, used as a rough control, and also with blasted/acid-etched surface. The evaluation of the BIC areas revealed the benefit of rough surfaces 
relative to machined ones. However, the intra-individual difference between the TPS and the blasted/acid-etched counterparts showed no significant difference.

In a different animal model, Klokkevold et al. (54) compared the torque resistance to remove screwshaped titanium implants having a dual acid-etched surface (DAE) with implants having either a machined surface, or a TPS surface that exhibited a significantly more complex surface topography. After implantation, the groups of 6 rabbits were sacrificed following 1-, 2- and 3-month healing periods. Implants were removed by reverse torque rotation with a digital torquemeasuring device. Three implants with machined surface preparation failed to achieve endosseous integration. All other implants were anchored by bone. Mean torque values for machined, DAE and TPS implants at 1, 2 and 3 months were $6.00 \pm 0.64 \mathrm{~N} / \mathrm{cm}, 9.07 \pm 0.67 \mathrm{~N} / \mathrm{cm}$ and $6.73 \pm 0.95 \mathrm{~N} / \mathrm{cm} ; 21.86 \pm 1.37 \mathrm{~N} / \mathrm{cm}, 27.63 \pm 3.41$ $\mathrm{N} / \mathrm{cm}$ and $27.40 \pm 3.89 \mathrm{~N} / \mathrm{cm}$; and $27.48 \pm 1.61 \mathrm{~N} / \mathrm{cm}$, $44.28 \pm 4.53 \mathrm{~N} / \mathrm{cm}$ and $59.23 \pm 3.88 \mathrm{~N} / \mathrm{cm}$, respectively. Clearly, the stability of DAE implants at the earliest time point was comparable to that of TPS implants, while that of the machined implants was an order of magnitude lower. The TPS implants increased resistance to reverse torque removal over the 3-month period. These results indicate that dual acid etching of titanium enhances early endosseous integration to a level that is comparable to that achieved by the topographically more complex TPS surfaces. Furthermore, this study confirmed an enhanced bone anchorage to rough surface implants as compared to machined implants.

TPS processing is one of the methods that further increase the surface roughness profile and consequently the surface area. Such characteristics recommend its use in regions with low bone density (12). However, it has to be considered that the increase in surface area that represents an effective increase in osseointegration area provides spaces greater than $50 \mu \mathrm{m}$ that facilitates the migration of pathogens when the implant surface is exposed to the oral fluids.

\section{Blasting with ceramic particles/acid-etching}

Surface acid-etching and grit-blasting/acidetching are very diffuse methods to obtain rough implant surfaces. A great part of the commercially available gritblasted implant surfaces are subsequently acid-etched.

Generally, the grit-blasting procedure is performed by propulsion of particles of different sizes of silica (sand), alumina, titanium oxide or $\mathrm{CaP}$ for example. The most commonly used acid-etching agents are hydrofluoric, nitric, sulfuric acids and combinations. An example of this group of surfaces was investigated by Sammons et al. (55), evidencing a $R a$ value of $2.75 \mu \mathrm{m}$ and irregular micropores with approximately $3-5 \mu \mathrm{m}$ in diameter and 2-3 $\mu \mathrm{m}$ in depth. Even smaller micropores are located within these micropores.

Novaes et al. (56) compared grit-blasted/acidetched implants to titanium plasma spray implants immediately installed into periodontally infected sites. The histomorphometric analyses showed percentages of bone to implant contact of $52.7 \%$ and $42.7 \%$ for grit-blasted/acid-etched implants and titanium plasma spray implants, respectively. The bone density analysis revealed percentages of $66.6 \%$ and $58.8 \%$ in the adjacent areas of grit-blasted/acid-etched implants and titanium plasma spray implants, respectively. These differences between the groups were not statistically significant, but indicated a slightly better performance of the gritblasted/acid-etched surfaces when compared to the titanium plasma spray surface, even in a challenging healing situation.

Recently, it was seen that changing the sterilization and storage method of an original sandblasted/acid-etched surface is another possible way to modify implant surface. In other words, the new surface is rinsed under nitrogen protection to prevent exposure to air and then stored in a sealed tube containing an isotonic saline solution (4). This treatment obtains the hydroxylation of titanium oxides without changing the surface topography, this procedure improved the surface wettability of the new surface when compared to the original one in a statistically significant level (57).

According to animal experiments, both biomechanical and histomorphometric evaluations showed better results for the modified surface compared to the original sand-blasted/acid-etched surface at early periods. In the miniature pig model, Buser et al. (58) investigated the interfacial stiffness values, which were calculated from the torque-rotation curve, and found on average $9-14 \%$ higher values for the modified surface compared to the original sand-blasted/ acid-etched surface. This difference was statistically significant and they concluded that the modified provided better bone anchorage than the original surface. Moreover, Schwarz et al. (59) evaluated the bone regeneration in dehiscence-type defects with these implants in beagle dogs. After 2 weeks of healing, the modified group 
achieved $74 \%$ of BIC, while the original group achieved $56 \%$, and this difference was statistically significant. However, after 12 weeks of healing, BIC was $84 \%$ for the modified group and $76 \%$ for the original group, without statistically significant and this difference. Thus, it could be concluded that the modified implant surface promoted enhanced bone apposition during the early stages of bone formation. In accordance to this, Bornstein et al. (60) comparing the same implant surfaces in a dog model, showed significantly higher percentage of bone in contact with the modified surface when compared to the original sand-blasted/acid-etched surface after 2 weeks, but no statistically significant difference after 4 weeks of implantation. These results suggest that a chemical modification on a microstructured implant surface may interfere in the biomechanical and bone apposition properties at early phases after implantation.

\section{Electrochemical anodization}

Another method that has been shown to increase surface microtexture and change surface chemistry is electrochemical anodization. The combination of potentiostatic or galvanostatic anodization of titanium in strong acids at high current density or potential, results in thickening of the titanium oxide layer. Anodized surfaces interfere positively in bone response with higher values for biomechanical and histomorphometric tests when compared to machined surfaces $(61,62)$.

Burgos et al. (63) selected a commercially implant surface manufactured by anodic oxidation to compare to turned surfaces in a rabbit model. BIC values were $20 \%$ (after 7 days), $23 \%$ (after 14 days), and $46 \%$ (after 28 days) around the oxidized surfaces and $15 \%$ (after 7 days), 11\% (after 14 days), and 26\% (after 28 days) around the machined surfaces. It was concluded that the moderately rough oxidized surfaces follows a different pattern of osseointegration.

Differently, Huang et al. (64) evaluated the oxidized implant surfaces installed in the posterior maxilla of monkeys. After 16 weeks, the mean BIC was of $74 \%$. The authors suggested that this oxidized surface detains a considerable osteoconductive potential promoting a high level of implant osseointegration in type IV bone in the posterior maxilla.

\section{CaP coatings}

Up to now, plasma-spraying remains as the most widely used commercial $\mathrm{CaP}$ implant surface coating. $\mathrm{CaP}$ ceramics are considered to have bioactive properties, which involves the strong interaction between materials and surrounding bone by means of a chemical bonding (2). Substrates containing $\mathrm{CaP}$ coating is expected to render a faster biological fixation between implant and bone tissue when compared to those without $\mathrm{CaP}$ coatings (65-67). However, the thick and non-uniform coating performed by the plasma-spraying method, in which HA ceramic particles are injected into a plasma torch at high temperature and projected on to the surface of the titanium, have also been related to some disadvantages. The possible delamination of the coating from the implant surface is generally highlighted, making possible the clinical failure of the implant (68). Additionally, the transmucosal zone of plasma sprayed HA implants represents a challenge (43) in terms of periimplantitis infection. Based on these reasons, the clinical use of the plasma sprayed HA implants decreased, but the osteoconductive property of this bioactive ceramic coating remains as a factor that may contribute to additional bone attachment in areas of poor quality or quantity of bone.

As a new trend, the changes of surface roughness at the nanoscale level seem to strongly influence the host response at both cellular and tissue levels. In this context, it should be mentioned that some strategies have been developed to improve the plasma sprayed HA coating process. Thus methods such as sol-gel deposition, electrophoretic deposition and discrete crystalline deposition were developed in order to obtain significant thinner coating thicknesses when compared to the plasma sprayed HA technique.

It is already available for clinical use the result of a $\mathrm{CaP}$ nanoparticle modification of a minimally rough titanium implant surface. It has been created by the combination of the sol-gel and discrete crystalline deposition (DCD) of CaP. Mendes et al. (69) suggested that the nano-feature size of the tightly adherent adsorbed $\mathrm{CaP} / \mathrm{DCD}$ crystal is of $20-100 \mathrm{~nm}$.

In the rat model, Mendes et al. (70) have shown significantly greater average disruption forces with DCD samples when compared to dual acid-etched samples. The authors concluded that an increase in the complexity of the surface topography can render a bone-bonding ability. Recently, the same group, again in the rat model (71), demonstrated significant increase in osteoconduction as a function of the enhanced surface nanotopography obtained by the CAP nanocrystals in 
the rat model.

In summary, highly roughened implants, such as TPS or grit-blasted implants, have been shown to favor mechanical anchorage and primary fixation to bone, while topographies in the nanometer level focus on the enhancement of the host response by means of promoting protein adsorption and osteoblastic cell adhesion during the early stages of healing in the periimplant region.

\section{BIOMIMETIC SURFACE MODIFICATIONS}

\section{Biomolecules coated onto titanium surface}

A common theme in the engineering of cell and tissue behavior on device surfaces is to modify the material to selectively interact with a specific cell type through biomolecular recognition events. Typically, peptides containing the cell-binding domains found in the extracellular matrix proteins are immobilized on the material to promote cell adhesion via ligandreceptor interaction $(72,73)$. Integrins are an example of cell adhesion receptors that bind to specific amino acid sequences, such as the RGD that is found in type I collagen, fibronectin, osteopontin and bone sialoprotein. Apart from cell attachment, extracellular matrix may also act on cellular migration and proliferation events.

The concept of functionalizing the implant surfaces with native or synthetic molecules based on peptides, proteins and growth factors emerged from the hypothesis that the ability of imitating the environment of bone, which is composed of an organic matrix (mainly collagenous proteins) and inorganic $\mathrm{CaP}$, could enhance the implant surface performance, encouraging the initial biologic response.

Animal studies support the in vivo osteoconductive potential of the RGD peptide sequence as a potential method of functionalizing titanium implant surfaces. In the dog model, Schliephake et al. (46) compared implants with machined titanium surface, coated with collagen I, coated with collagen I and low RGD concentrations $(100 \mu \mathrm{mol} / \mathrm{mL})$, and coated with collagen I and high RGD concentrations $(1000 \mu \mathrm{mol} / \mathrm{mL})$. The BIC and volume density of the newly formed periimplant bone (BVD) was assessed histomorphometrically after 1 and 3 months. After 1 month, BIC was significantly enhanced only in the group of implants coated with the higher concentration of RGD peptides. Volume density of the newly formed periimplant bone was significantly higher in all implants with organic coating. No significant difference was found between collagen coating and RGD coatings. After 3 months, BIC was significantly higher in all implants with organic coating than in implants with machined surfaces. Periimplant BVD was significantly increased in all coated implants in comparison to machined surfaces. The authors concluded that organic coating of machined screw implant surfaces providing binding sites for integrin receptors can enhance bone implant contact and periimplant bone formation. In addition, Germanier et al. (74) compared RGD peptide polymer modified implant surfaces with sandblasted and acid-etched implant surfaces placed in the maxillae of miniature pigs, and confirmed that the functionalization may promote enhanced bone apposition during the early stages of bone regeneration.

However,it should be mentioned that the success of such functionalization seems to be strongly dependent on type, delivery and concentration of the coating. For example, some studies showed confusing results when evaluating implant surfaces modified by BMP coatings. BMPs are a class of growth factors that promote bone formation, but they also stimulate the action of osteoclasts. It seems that the dose of the drug is critical for the final result.

Liu et al. (75) evaluated the effects of BMP-2 and its mode of delivery on the osteoconductivity of dental implants with either a naked titanium surface or a calcium-phosphate-coated one in the maxillae of miniature pigs. After 3 weeks, the volume of bone deposited within the osteoconductive space (periimplant) was highest for coated and uncoated implants bearing no BMP-2, while the lowest value was achieved with coated implants bearing only adsorbed BMP-2. It was concluded that the osteoconductivity of functionalized implant surfaces depends on the mode of BMP-2 delivery, being drastically impaired when BMP-2 was present as a superficially adsorbed depot upon $\mathrm{CaP}$ coated or uncoated surfaces.

In a different dog model, Wikesjö et al. (76) studied the ability of recombinant human BMP-2 (rhBMP-2) coated onto a titanium porous oxide implant surface to stimulate local bone formation, including osseointegration and vertical augmentation of the alveolar ridge. Thus critical-size, $5 \mathrm{~mm}$, supraalveolar, periimplant defects were created and implants coated with rhBMP-2 at 0.75 or 1.5 or $3.0 \mathrm{mg} / \mathrm{mL}$ or uncoated control were installed and compared. The histologic evaluation showed newly formed bone with characteristics of the adjoining resident type II bone 
including cortex formation for sites receiving implants coated with rhBMP-2 at 0.75 or $1.5 \mathrm{mg} / \mathrm{mL}$. Sites receiving implants coated with rhBMP-2 at $3.0 \mathrm{mg} / \mathrm{mL}$ exhibited more immature trabecular bone formation, seroma formation and periimplant bone remodelling resulting in undesirable implant displacement. Control implants exhibited minimal, if any, bone formation. In summary, rhBMP-2 coating onto titanium porous oxide implant surfaces induced clinically relevant local bone formation including vertical augmentation of the alveolar ridge and osseointegration, but higher concentrations/ doses were associated with negative effects.

Finally, non-BMP growth factors have also been tested as potential agents to improve the osseointegration parameters. Park et al. (77) evaluated the osseointegration of anodized titanium implants coated with fibroblast growth factor-fibronectin (FGF-FN) fusion protein that were placed in rabbit tibiae. The removal torque values as well as the percentages of BIC of the test group were better than those found for the implants that were not biofunctionalized.

\section{CONCLUDING REMARKS}

There are a huge number of types of implant surfaces in the market, from different implant manufacturers, all of them claiming to have better clinical results. It is important that the clinician selects for use in their patients the surfaces that have shown good results in the scientific literature.

The majority of currently available in vitro and in vivo studies seem to indicate that implant surfaces with micro and submicro (nano) topography bring forward benefits to the process of interaction between bone cells and implant surfaces, accelerating and increasing the quality of BIC.

Finally, based on the state of the art of implant development, it is possible to predict that, within some time, implant surfaces coated with substances with biomimetic capacity will be available for clinical use. This process of biofuncionalization of implant aims at modulating new bone formation around implants, and it is the next step in implant development.

\section{RESUMO}

A fixação biológica entre as superfícies de implante e os ossos maxilares deve ser considerada como um pré-requisito para o sucesso em longo prazo de próteses implanto-suportadas. Neste contexto, as modificações nas superfícies de implante ganharam um lugar importante e decisivo na pesquisa em Implantodontia nos últimos anos. Sendo o tópico mais estudado, colaboraram para o melhoramento de modalidades de tratamento dental, assim como para a expansão de uso dos implantes dentais. Hoje, um grande número de diferentes implantes com uma grande variedade de propriedades de superfícies, entre outras características, está comercialmente disponível e isto deve ser tratado com cuidado. Apesar das modificações nas superfícies terem melhorado a osseointegração em tempos precoces de implantação, por exemplo, o clínico deve procurar evidências científicas antes de selecionar um implante dental para uso específico. Este artigo fará uma revisão da literatura sobre superfícies de implantes osseointegráveis, analisando estudos in vitro e in vivo, a fim de mostrar uma perspectiva atual do desenvolvimento dos implantes. Esta abordagem englobará os resultados obtidos com micro e nano topografias, em termos quantitativos e qualitativos, avaliando a interface osso-implante. Além disso, discutirá também as perspectivas da incorporação de substâncias biomiméticas (como peptídeos e proteínas morfogenéticas) à superfície dos implantes e seus efeitos na modulação da neoformação óssea periimplantar.

\section{REFERENCES}

1. Albrektsson T, Wennerberg A. Oral implant surfaces: Part 1- review focusing on topographic and chemical properties of different surfaces and in vivo responses to them. Int J Prosthodont 2004; 17:536-543.

2. Junker R, Dimakis A, Thoneick M, Jansen JA. Effects of implant surface coatings and composition on bone integration: a systematic review. Clin Oral Implants Res 2009;20:185-206.

3. Buser D, Broggini N, Wieland M, Schenk RK, Denzer AJ, Cochran DL, et al.. Enhanced bone apposition to a chemically modified SLA titanium surface. J Dent Res 2004;83:529-533.

4. Zhao G, Schwartz Z, Wieland M, Rupp F, Geis-Gerstorfer J, Cochran DL, et al.. High surface energy enhances cell response to titanium substrate microstructure. J Biomed Mater Res A 2005;74:49-58

5. Wong M, Eulenberger J, Schenk R, Hunziker E. Effect of surface topology on the osseointegration of implant materials in trabecular bone. J Biomed Mater Res 1995;29:1567-1575.

6. Wennerberg A, Albrektsson T. On implant surfaces: a review of current knowledge and opinions. Int J Oral Maxillofac Implants 2010;25:63-74.

7. Wennerberg A, Albrektsson T. Effects of titanium surface topography on bone integration: a systematic review. Clin Oral Implants Res 2009;20:172-184.

8. Beutner R, Michael J, Schwenzer B, Scharnweber D. Biological nano-functionalization of titanium-based biomaterial surfaces: a flexible toolbox. J R Soc Interface 2010;7:S93-S105.

9. Barros RR, Novaes AB Jr, Papalexiou V, Souza SL, Taba M Jr, Palioto DB, et al.. Effect of biofunctionalized implant surface on osseointegration: a histomorphometric study in dogs. Braz Dent J 2009;20:91-98.

10. Lutz R, Srour S, Nonhoff J, Weisel T, Damien CJ, Schlegel KA. Biofunctionalization of titanium implants with a biomimetic active peptide (P-15) promotes early osseointegration. Clin Oral Implants Res 2010;21:726-734.

11. Binon PP. Implants and components: entering the new millennium. Int J Oral Maxillofac Implants 2000;15:76-94.

12. Coelho PG, Granjeiro JM, Romanos GE, Suzuki M, Silva NR, Cardaropoli $\mathrm{G}$, et al.. Basic research methods and current trends 
of dental implant surfaces. J Biomed Mater Res B Appl Biomater 2009;88:579-596.

13. Lemons JE. Biomaterials, biomechanics, tissue healing, and immediate-function dental implants. J Oral Implantol 2004;30:318-324.

14. Anselme K. Osteoblast adhesio on biomaterials. Biomaterials 2000;21:667-681.

15. Kasemo B. Biological surface science. Surf Sci 2002;500:656-677.

16. Deligianni DD, Katsala N, Ladas S, Sotiropoulou D, Amedee J, Missirlis YF. Effect of surface roughness of the titanium alloy Ti$6 \mathrm{Al}-4 \mathrm{~V}$ on human broadcast marrow cell response and on protein adsorption. Biomaterials 2001;22:1241-1251.

17. Lamers E, Walboomers XF, Domanski M, te Riet J, van Delft FC, Luttge $\mathrm{R}$, et al.. The influence of nanoscale grooved substrates on osteoblast behavior and extracellular matrix deposition. Biomaterials 2010;31:3307-3316.

18. Mendonça G, Mendonça DB, Aragão FJ, Cooper LF. The combination of micron and nanotopography by $\mathrm{H}(2) \mathrm{SO}(4) / \mathrm{H}(2)$ $\mathrm{O}(2)$ treatment and its effects on osteoblast-specific gene expression of hMSCs. J Biomed Mater Res A 2010;94:169-179.

19. Lincks J, Boyan BD, Blanchard CR, Lohmann CH, Liu Y, Cochran DL, et al.. Response of MG63 osteoblast-like cells to titanium and titanium alloy is dependent on surface roughness and composition. Biomaterials 1998;19:2219-2232.

20. von der Mark K, Park J, Bauer S, Schmuki P. Nanoscale engineering of biomimetic surfaces: cues from the extracellular matrix. Cell Tissue Res 2010;339:131-153.

21. Anselme K, Bigerelle M. Topography effects of pure titanium substrates on human osteoblast long-term adhesion. Acta Biomater 2005;1:211-222.

22. Cooper LF, Masuda T, Yliheikkila PK, Felton DA. Generalizations regarding the process and phenomenon of osseointegration. Part II. In vitro studies. Int J Oral Maxillofac Impl 1998;13:163-174.

23. Davies JE. Mechanisms of endosseous integration. Int $\mathrm{J}$ Prosthodont 1998;11:391-401.

24. Lim YJ, Oshida Y, Andres CJ, Barco MT. Surface characterizations of variously treated titanium materials. Int J Oral Maxillof Imp 2001;16:333-342.

25. Dohan Ehrenfest DM, Coelho PG, Kang BS, Sul YT, Albrektsson T. Classification of osseointegrated implant surfaces: materials, chemistry and topography. Trends Biotechnol 2010;28:198-206.

26. Wennerberg A, Albrektsson T. Suggested guidelines for the topographic evaluation of implant surfaces. Int J Oral Maxillofac Implants 2000;15:331-344.

27. Le Guéhennec L, Soueidan A, Layrolle P, Amouriq Y. Surface treatments of titanium dental implants for rapid osseointegration. Dent Mater 2007;23:844-854.

28. Healy KE, Thomas CH, Rezania A, Kim JE, McKeown PJ, Lom $\mathrm{B}$, et al.. Kinetics of bone cell organization and mineralization on materials with patterned surface chemistry. Biomaterials 1996;17:195-208.

29. Rosa AL, Beloti MM. Effect of cpTi surface roughness on human bone marrow cell attachment, proliferation, and differentiation. Braz Dent J 2003;14:16-21.

30. Zinger O, Anselme K, Denzer A, Habersetzer P, Wieland M, Jeanfils J, et al.. Time-dependent morphology and adhesion of osteoblastic cells on titanium model surfaces featuring scaleresolved topography. Biomaterials 2004;25:2695-2711.

31. Mustafa K, Wennerberg A, Wroblewski J, Hultenby K, Lopez BS, Arvidson K. Determining optimal surface roughness of $\mathrm{TiO}(2)$ blasted titanium implant material for attachment, proliferation and differentiation of cells derived from human mandibular alveolar bone. Clin Oral Implants Res 2001;12:515-525.

32. Wieland M, Textor M, Chehroudi B, Brunette DM. Synergistic interaction of topographic features in the production of bonelike nodules on $\mathrm{Ti}$ surfaces by rat osteoblasts. Biomaterials 2005;26:1119-1130.

33. Matsuzaka K, Walboomers XF, Yoshinari M, Inoue T, Jansen JA The attachment and growth behavior of osteoblast-like cells on microtextured surfaces. Biomaterials 2003;24:2711-2719.

34. Boyan BD, Lossdorfer S, Wang L, Zhao G, Lohmann CH, Cochran DL, et al.. Osteoblasts generate an osteogenic microenvironment when grown on surfaces with rough microtopographies. Eur Cell Mater 2003;6:22-27.

35. Schwartz Z, Lohmann CH, Oefinger J, Bonewald LF, Dean $\mathrm{DD}$, Boyan BD. Implant surface characteristics modulate differentiation behavior of cells in the osteoblastic lineage. Adv Dent Res 1999;13:38-48.

36. Schwartz Fo HO, Novaes AB Jr, de Castro LMS, Rosa AL, de Oliveira PT. In vitro osteogenesis on a microstructured titanium surface with additional submicron-scale topography. Clin Oral Implants Res 2007;18:333-344.

37. De Oliveira PT, Nanci A. Nanotexturing of titanium-based surfaces upregulates expression of bone sialoprotein and osteopontin by cultured osteogenic cells. Biomaterials 2004;25:403-413.

38. De Oliveira PT, Zalzal SF, Beloti MM, Rosa AL, Nanci A. Enhancement of in vitro osteogenesis on titanium by chemically produced nanotopography. J Biomed Mater Res A 2007;80:554564.

39. Schneider GB, Zaharias R, Stanford C. Osteoblast integrin adhesion and signaling regulate mineralization. J Dent Res 2001;80:1540-1544.

40. Variola F, Yi JH, Richert L, Wuest JD, Rosei F, Nanci A. Tailoring the surface properties of Ti6A14V by controlled chemical oxidation. Biomaterials 2008;29:1285-1298.

41. Vetrone F, Variola F, Tambasco de Oliveira P, Zalzal SF, Yi JH, Sam J, et al.. Nanoscale oxidative patterning of metallic surfaces to modulate cell activity and fate. Nano Lett 2009;9:659-665.

42. Liu Y, de Groot K, Hunziker EB. Osteoinductive implants: the mise-en-scène for drug-bearing biomimetic coatings. Ann Biomed Eng 2004;32:398-406.

43. Yang Y, Kim KH, Ong JL. A review on calcium phosphate coatings produced using a sputtering process-an alternative to plasma spraying. Biomaterials 2005;26:327-337.

44. Barrère F, Layrolle $P$, van Blitterswijk CA, de Groot K. Biomimetic calcium phosphate coatings on Ti6AI4V: a crystal growth study of octacalcium phosphate and inhibition by $\mathrm{Mg} 2+$ and $\mathrm{HCO} 3-$. Bone 1999;25:107S-111S.

45. Tosatti S, Schwartz Z, Campbell C, Cochran DL, Vandevondele S, Hubbel JA, et al.. RGD-containing peptide GCRGYGRGDSPG reduces enhancement of osteoblast differentiation by poly(Llysine)-graft-poly(ethylene glycol)-coated titanium surfaces. J Biomed Mater Res A 2004;68:458-472.

46. Schliephake H, Scharnweber D, Dard M, Sewing A, Aref A, Roessler S. Functionalization of dental implant surfaces using adhesion molecules. J Biomed Mater Res B Appl Biomater 2005;73:88-96

47. Puleo DA, Nanci A. Understanding and controlling the boneimplant interface. Biomaterials 1999;20:2311-2321.

48. Geissler U, Hempel U, Wolf C, Scharnweber D, Worch H, Wenzel KW. Collagen type I coating of Ti6Al4V promotes adhesion of osteoblasts. J Biomed Mater Res 2000;51:752-760.

49. Mizuno M, Imai T, Fujisawa R, Tani H, Kuboki Y. Bone sialoprotein (BSP) is a crucial factor for the expression of osteoblastic phenotypes of bone marrow cells cultured on type I collagen matrix. Calcif Tissue Int 2000;66:388-396.

50. De Assis AF, Beloti MM, Crippa GE, de Oliveira PT, Morra M, Rosa AL. Development of the osteoblastic phenotype in human 
alveolar bone-derived cells grown on a collagen type I-coated titanium surface. Clin Oral Implants Res 2009;20:240-246.

51. Cooper LF, Zhou Y, Takebe J, Guo J, Abron A, Holmén A, et al.. Fluoride modification effects on osteoblast behavior and bone formation at $\mathrm{TiO} 2$ grit-blasted c.p. titanium endosseous implants. Biomaterials 2006;27:926-936.

52. Albrektsson T, Sennerby L. State of the art in oral implants. J Clin Periodontol 1991;18:474-481.

53. Al-Nawas B, Groetz KA, Goetz H, Duschner H, Wagner W. Comparative histomorphometry and resonance frequency analysis of implants with moderately rough surfaces in a loaded animal model. Clin Oral Implants Res 2008;19:1-8.

54. Klokkevold PR, Johnson P, Dadgostari S, Caputo A, Davies JE, Nishimura RD. Early endosseous integration enhanced by dual acid etching of titanium: a torque removal study in the rabbit. Clin Oral Implants Res 2001;12:350-357.

55. Sammons RL, Lumbikanonda N, Gross M, Cantzler P. Comparison of osteoblast spreading on microstructured dental implant surfaces and cell behavior in an explants model of osseointegration. A scanning electron microscopy study. Clin Oral Implants Res 2005; 16:657-666.

56. Novaes AB Jr, Papalexiou V, Grisi MF, Souza SS, Taba M $\mathrm{Jr}$, Kajiwara JK. Influence of implant microstructure on the osseointegration of immediate implants placed in periodontally infected sites. A histomorphometric study in dogs. Clin Oral Implants Res 2004;15:34-43.

57. Rupp F, Scheideler L, Olshanska N, de Wild M, Wieland M, GeisGerstorfer J. Enhancing surface free energy and hydrophilicity through chemical modification of microstructure titanium implant surfaces. J Biomed Mater Res A 2006;76:323-334.

58. Buser D, Nydegger T, Oxland T, Cochran DL, Schenk RK, Hirt HP, et al.. Interface shear strength of titanium implants with a sandblasted and acid-etched surface: a biomechanical study in the maxilla of miniature pigs. J Biomed Mater Res 1999;45:75-83.

59. Schwarz F, Herten M, Sager M, Wieland M, Dard M, Becker $\mathrm{J}$. Bone regeneration in dehiscence-type defects at chemically modified (SLAactive ${ }^{\mathbb{R}}$ ) and conventional SLA titanium implants: a pilot study in dogs. J Clin Periodontol 2007;34:78-86.

60. Bornstein MM, Valderrama P, Jones AA, Wilson TG, Seibl R, Cochran DL. Bone apposition around two different sandblasted and acid-etched titanium implant surfaces: a histomorphometric study in canine mandibles. Clin Oral Impl Res 2008;19:233-241.

61. Sul YT, Johansson CB, Jeong Y, Wennerberg A, Albrektsson T. Resonance frequency and remova 1 torque analysis of implants with turned and anodized surface oxides. Clin Oral Implants Res 2002;13:252-259.

62. Rocci A, Martignoni M, Gottlow J. Immediate loading of Branemark System TiUnite and machined-surface implants in the posterior mandible: a randomized open-ended clinical trial. Clin Implant Dent Relat Res 2003;5:557-563.

63. Burgos PM, Rasmusson L, Meirelles L, Senerby L. Early bone tissue responses to turned and oxidized implants in a rabbit tibia. Clin Impl Dent Relat Res 2008;10:181-190.
64. Huang YH, Xiropaidis AV, Sorensen RG, Albandar JM, Hall J, Wikesjö UME. Bone formation of titanium porous oxide (TiUnite) oral implants in type IV bone. Clin Oral Impl Res 2005;16:105111.

65. Barrère F, van der Valk CM, Meijer G, Dalmeijer RA, de Groot K, Layrolle P. Osteointegration of biomimetic apatite coating applied onto dense and porous metal implants in femurs of goats. J Biomed Mater Res 2003;67:655-665.

66. Quaranta A, Iezzi G, Scarano A, Coelho PG, Vozza I, Marincola $\mathrm{M}$, et al.. A histomorphometric study of nanothickness and plasmasprayed calcium-phosphorous-coated implant surfaces in rabbit bone. J Periodontol 2010;81:556-561.

67. Yang GL, He FM, Hu JA, Wang XX, Zhao SF. Biomechanical comparison of biomimetically and electrochemically deposited hydroxyapatite-coated porous titanium implants. J Oral Maxillofac Surg 2010;68:420-427.

68. Lee J, Rouhfar L, Beirne O. Survival of hydroxypatite-coated implants: a meta-analytic review. J Oral Maxillofac Surg 2000;58:1372-1379.

69. Mendes VC, Moineddin R, Davies JE. Discrete calcium phosphate nanocrystalline deposition enhances osteoconduction on titaniumbased implant surfaces. J Biomed Mater Res A 2009;90:577-585.

70. Mendes VC, Moineddin R, Davies JE. The effect of discrete calcium phosphate nanocrystals on bone-bonding to titanium surfaces. Biomaterials 2007;28:4748-4755.

71. Mendes VC, Moineddin R, Davies JE. Discrete calcium phosphate nanocrystalline deposition enhances osteoconduction on titaniumbased implant surfaces. J Biomed Mater Res A 2009;90:577-585.

72. Rezania A, Healy KE. Biomimetic peptide surfaces that regulate adhesion, spreading, cytoskeletal organization, and mineralization of the matrix deposited by osteoblast-like cells. Biotechnol Prog 1999;15:19-32.

73. Rezania A, Thomas CH, Branger AB, Waters CM, Healy KE. The detachment strength and morphology of bone cells contacting materials modified with a peptide sequence found within bone sialoprotein. J Biomed Mater Res 1997;37:9-19.

74. Germanier Y, Tosatti S, Broggini N, Textor M, Buser D. Enhanced bone apposition around biofunctionalized sandblasted and acidetched titanium implant surfaces. A histomorphometric study in miniature pigs. Clin Oral Impl Res 2006;17:251-257.

75. Liu Y, Enggist L, Kuffer AF, Buser D, Hunziker EB. The influence of BMP-2 and its mode of delivery on the osteoconductivity of implant surfaces during the early phase of osseointegration. Biomaterials 2007;28:2677-2686.

76. Wikesjö UM, Qahash M, Polimeni G, Susin C, Shanaman RH, Rohrer MD, et al.. Alveolar ridge augmentation using implants coated with recombinant human bone morphogenetic protein-2: histologic observations. J Clin Periodontol 2008;35:1001-1010.

77. Park JM, Koak JY, Jang JH, Han CH, Kim SK, Heo SJ. Osseointegration of anodized titanium implants coated with fibroblast growth factor-fibronectin (FGF-FN) fusion protein. Int J Oral Maxillofac Implants 2006;21:859-866. 